75 years of Agricultural University - Plovdiv

JUBILEE SCIENTIFIC INTERNATIONAL

CONFERENCE Plovdiv 26-28 November 2020
PERSPECTIVES ON AGRICULTURAL SCIENCE AND INNOVATIONS FOR SUSTAINABLE FOOD SYSTEMS

\title{
DOI: 10.22620 /agrisci.2021.30.013 \\ INFLUENCE OF FOLIAR FERTILIZER PANAMIN AGRO ON THE GROWTH AND DECORATIVE CHARACTERISTICS OF TAGETES SPECIES IN LEAF APPLICATION
}

\author{
Valeria Ivanova \\ Agricultural University - Plovdiv, Plovdiv, Bulgaria \\ E-mail: valeriasi1@abv.bg
}

\begin{abstract}
Species of the genus Tagetes are some of the most common plants in gardening practice in Bulgaria. One of the key problems in the production of planting material of these species is the slow growth of seedlings in the beginning of their cultivating. The application of foliar fertilizers is one way to solve this problem. This study examines the impact of foliar fertilizer Panamin Agro on growth processes and biometric characteristics of three species of tagetes: $T$. erecta L.; T. patula L.. and $T$. signata Bartl. Foliar fertilizer Panamin Agro was used in 3 different concentrations: $0.5 \% ; 1.0 \%$ and $1.5 \%$. The treatment started with the formation of the first true leaf in $90 \%$ of the cultivated plants and was applied every 14 days three times until the seedlings were taken outdoors and planted in a permanent place. It was found that the growth characteristics of the treated plants exceed substantially those of the untreated control plants. With the highest and thickest stems of plants, the highest number and size of leaves and flowers and accelerated, enhanced and prolonged the period of photosynthesis are three species of tagetes treated with $1.0 \%$ PanaminAgro. Treatment with a concentration of $1.5 \%$ does not always have a positive effect on the growth characteristics of the treated plants. The effect of leaf treatment with PanaminAgro on the biometric characteristics of the root system is insignificant. We offer the use of PanaminAgro in the nursery practice in the production of planting material of african marigold in a concentration of $1.0 \%$.
\end{abstract}

Keywords: Tagetes, foliar fertilizer, Panamin Agro, biometrical characteristics.

\section{INTRODUCTION}

Representatives of the genus Tagetes are one of the most popular, most commonly used and most preferred flowering annuals grown in our country. The reasons are in the great variety of species and varieties, the bright signal colors of the flowers, the long flowering of the individual flower and the whole plant, as well as the relative tolerance to attack by diseases and pests. These plants are grown not only as ornamentals, but also as a source of natural carotenoid pigment, which is used in the composition of poultry supplements, pharmaceuticals, cosmetics, textiles and others. (Benk et al., 1976; Dumbovsky et al.,
1980; Kasumov, 1984; Kasumov, 1991; Narahari et al., 1981; Takki et al., 1991; Wild and Dobrovolny, 1976). All this arouses great interest in this culture and requires detailed development of the main points of the technology of cultivation. Kumar, P. et al. (2010) investigated the pre-sowing treatment of tagetes seeds and its influence on the decorative characteristics of this species. Adverse environmental conditions and in particular high salt content in the soil solution are studied by El-Kinany, R. Et al., 2014. New sources of macro and microfertilizers and different levels of their application are the subject of research by Pal and Ghosh, 2010; Sanghamitra, V., B. Et al., 2000. A number of 
75 years of Agricultural University - Plovdiv JUBILEE SCIENTIFIC INTERNATIONAL CONFERENCE Plovdiv 26-28 November 2020
PERSPECTIVES ON AGRICULTURAL SCIENCE AND INNOVATIONS FOR SUSTAINABLE FOOD SYSTEMS authors are working on the use of chemical and biological fertilizers to enhance the growth and decorative characteristics of tagetes (Al Badawy et al., 1993; Das et al., 1975; Gowda and Jayanthi , 1994; Hore and Sen, 1986; Kumar et al., 1991; peat and Summerfield, 1977; Sharova and Savva, 1974; Smalley et al., 1993; Tsurushima and Date, 1971). One of the key problems in the production of seedlings of these species is the slow growth of seedlings at the beginning of their cultivation. The application of foliar fertilizers is one of the ways to solve this problem. However, the international standards for protection of the natural environment and human health require us to comply with the type of fertilizers and preparations used, the norms and conditions for their application, so that the residues in plant production and soil are in the permissible quantities (Malinova, 2007; ). A large number of ecologically clean fertilizers are massproduced and offered on the market, which have not been studied in all crops (Valchovski et al., 2007). In order to ensure a balanced diet, guaranteeing optimal growth and development of ornamental plants, it is necessary to develop a rational fertilization system, including soil and foliar nutrition (Ivanova and Kadum, 1996; Sapundzhieva et al., 2001; Ivanova et al., 2005). In Bulgaria, research on ecological fertilizers in ornamental plants is limited and insufficient. Such experiments have been performed only on some ornamental species (asters, gypsophila, calendula, carnation, chrysanthemum, lily, etc.). A number of authors study the influence of complex mineral fertilizers - Lactofol, Vege, Kristalon and HortiGrow (Ivanova et al., 1995; Atanasova et al., 1999; Kotopanova et al., 1999; Filipova et al. 1999; Atanasova et al. 2000; Kotopanova and Atanasova, 2008; Atanasova, 2012; Atanasova, 2013). The effect of fertilization with organic fertilizers - Lumbricol, Biostim, Humustim and Baikal - on the growth and development of species for cut flowers (mini carnation, chrysanthemum and gypsophila), for potted flowering species (petunia, impatience, mini rose, carnation and chrysanthemum) Atanassova et al., 2007; Kotopanova and Nencheva, 2008; Atanasova, 2011a; Atanasova, 2012; Atanasova and Nencheva, 2012; Zapryanova and Atanassova, 2013. The aim of the present study is to investigate the effect of PanaminAgro biomineral fertilizer on the growth and development of three species of the genus Tagetes and to determine the optimal concentration for the treatment of plants in the seedling phase.

\section{MATERIALS AND METHODS}

During the period 2017-2019 at the Agricultural University - Plovdiv was conducted pot experiment with three species of the genus Tagetes - T. erecta L .; T. patula L .. and $\mathrm{T}$. signata Bartl. to study the effect of PanaminAgro biomineral fertilizer on foliar treatment of seedlings in the following concentrations $\quad 0.5 \%, \quad 1.0 \%, \quad 1.5 \%$. PanaminAgro is a mixture of rock flours extracted from volcanic rocks, minerals and limestone. The main ingredients are $\mathrm{CaCO} 3$, $\mathrm{MgCO} 3, \mathrm{SiO} 2$ and the micro and macro elements: $\mathrm{K}, \mathrm{Zn}, \mathrm{Fe}, \mathrm{P}$ and naturally bound $\mathrm{CO} 2$. The natural origin of the preparation and its fine particles allow the ingredients of PANAMIN AGRO ${ }^{\circledR}$ to be completely assimilated and to accumulate as a stock in the plants. Upon penetration into the leaves, the natural decomposition of the two carbonates $(\mathrm{CaCO} 3$ and $\mathrm{MgCO} 3$ ) leads to the storage of the plant with naturally bound $\mathrm{CO} 2$, which accelerates, enhances and prolongs the period of photosynthesis. The manufacturer of the preparation is PANAMIN GmbH, Austria. The varieties Tagetes erecta Super giant (Hamzaden, The Netherlands) were used for the experiment; Tagetes patula Safari Scarlet and Tagetes pumila Pumila gnome. The seeds were sown in 
75 years of Agricultural University - Plovdiv JUBILEE SCIENTIFIC INTERNATIONAL CONFERENCE Plovdiv 26-28 November 2020
PERSPECTIVES ON AGRICULTURAL SCIENCE AND INNOVATIONS FOR SUSTAINABLE FOOD SYSTEMS the second half of March in a polyethylene greenhouse, in flower boxes, in a substrate of enriched peat and perlite, in a ratio of 2: 0.5 . The experiment was set up in three variants with concentrations of $0.5 \% ; 1.0 \%$ and $1.5 \%$, with 10 plants in each variant, and untreated plants were used as controls. The treatment started after $90 \%$ of the sprouted plants formed the first true leaf and was applied three times in 14 days until the seedlings were taken outdoors and planted in a permanent place. Measurements of the height, diameter and stem branches of the plant stem, the number and size of leaves, the number and size of flowers, as well as the indicators of the root system were performed at the end of the experiment. Statistical data processing was performed by analysis of variance of the results (Genchev et al., Dimova et al., 1999).

\section{RESULTS AND DISCUSSION}

Data on the effect of foliar treatment with Panamin on the characteristics of the root system in Tagetes species are presented in Table 1. The length of the root system in Tagetes erecta varies from $11.4 \mathrm{~cm}$ in the untreated variant to $18.9 \mathrm{~cm}$ in the variant treated with $1.5 \%$ concentration of Panamin . Impressively much higher valuesof this indicator in plants from the treated variant by $7.3 \mathrm{~cm} ; 6.4 \mathrm{~cm}$ and $7.5 \mathrm{~cm}$ exceed the control variant or by $64.0 \%$, $56.1 \%, 65.8 \%$ respectively. However, a twofold or threefold increase in Panamin concentration did not significantly affect the root length of the treated plants. The number of branches of the root system in the same species is quite high, both in the control variant and in the treated plants - varies from 178.4 pcs. up to 218.7 pcs. respectively in the control and in the treatment with a concentration of $1.0 \%$ variant. These data are not uncommon and can be explained by the fact that tagetes seedlings are produced by multiple dives, which leads to branching of the root system and, accordingly, to the presence of a large number of branches in it. This explains the large number of branches in the control variant - 178.4 pcs. and the small differences with the experimental variants - respectively 23.1 pcs ; 40.3 pcs. and 16.4 pcs. It is noteworthy that the variant with the longest length of the root system - variant 4 with a concentration of Panamin 1.5\% - has a relatively small number of branches - 194.8 pcs. and exceeds the control by only 16.4 pcs. branches. Regarding the volume of the root system of the plants of Tagetes erecta with the largest volume are those treated with a concentration of $1.0 \%$ Panamin - $293.5 \mathrm{~cm} 3$. They exceed the control by $35.7 \mathrm{~cm} 3$ or by $13.8 \%$. The differences with the other experimental variants were $8.0 \%$ and $11.6 \%$, respectively, for the plants treated with $0.5 \%$ and $1.5 \%$ concentration of Panamin. The length of the root system in Tagetes patula ranges between $5.3 \mathrm{~cm}$ for plants treated with $0.5 \%$ Panamin to $7.8 \mathrm{~cm}$ for plants treated with $1.0 \%$ of the preparation. The plants from the control variant and those treated with $0.5 \%$ Panamin have almost the same length of the root system $-5.8 \mathrm{~cm}$ and $5.3 \mathrm{~cm}$, respectively, and even in untreated plants the length is longer, although only $0.3 \mathrm{~cm}$. At high concentrations of Panamin and the response to this indicator is 7.8 $\mathrm{cm}$ for those treated with a concentration of $1.0 \%$ and $7.7 \mathrm{~cm}$ for those treated with a concentration of $1.5 \%$. The differences compared to the control were $2.0 \mathrm{~cm}$ and $1.9 \mathrm{~cm}$, respectively, which represents $34.5 \%$ and $32.8 \%$. With the largest number of branches of the root system in this species are the plants treated with $1.5 \%$ Panamin - 121.7 pcs., Which exceed the control by 23.3 pcs. or $13.03 \%$. The plants treated with $0.5 \%$ and $1.0 \%$ Panamin have almost the same number of branches of the root system $107.8 \mathrm{pcs}$. and $111.5 \mathrm{pcs}$. as the difference of 3.7 pcs. is in favor of higher concentration. Data from the results for the length and number of branches of the root system correlate with those for the volume in the species Tagetes patula. The largest volume $131.8 \mathrm{~cm} 3$ has the root system of plants treated 
75 years of Agricultural University - Plovdiv JUBILEE SCIENTIFIC INTERNATIONAL CONFERENCE Plovdiv 26-28 November 2020
PERSPECTIVES ON AGRICULTURAL SCIENCE AND INNOVATIONS FOR SUSTAINABLE FOOD SYSTEMS with $1.5 \%$ Panamin. The value of this indicator for untreated plants is $94.8 \mathrm{~cm} 3$, or $28.3 \mathrm{~cm} 3$, respectively; $23.0 \mathrm{~cm} 3,34.0 \mathrm{~cm} 3$ less than the volume of the root system of plants treated with $0.5 \% ; 1.0 \%$ and $1.5 \%$. Again, the values of this indicator in the plants treated with $0.5 \%$ and $1.0 \%$ are very close and in favor of the treatment with the lower concentration - the difference is $5.3 \mathrm{~cm} 3$ for the plants treated with $0.5 \%$ Panamin. The plants with 1.0\% Panamin - 4.5 $\mathrm{cm}$ have the longest roots in Tagetes signata, while the plants treated with $1.5 \%$ Panamin - 4.4 $\mathrm{cm}$ and $0.5 \%$ Panamin $-4.1 \%$ have very close values. The differences compared to the control are $1.3 \mathrm{~cm}$, respectively; $1.2 \mathrm{~cm}$ and $1.1 \mathrm{~cm}$. The high concentration of Panamin leads to the production of plants with the largest number of branches of the root system - 73.2, which is $50.3 \%$ more than the control. Plants treated with $0.5 \%$ and $1.0 \%$ Panamin formed 17.6 pcs. and 11.5 pcs. fewer branches than the best option and with 6.9 pcs. and 13.0 pcs. more than control. A similar trend is observed in the volume of the root system in Tagetes signata. The highest values are the plants treated with 1.5\% Panamin - $90.3 \mathrm{~cm} 3$, and the excess over the control is $21.6 \mathrm{~cm} 3$ or $31.4 \%$. With $5.1 \mathrm{~cm} 3$ and $18.8 \mathrm{~cm} 3$, the plants treated with $0.5 \%$ and $0.1 \%$ Panamin exceeded the control.

While the characteristics of the root system affect the overall growth and development of plants, the parameters of the stem mainly determine its decorative value. This is mainly the height and branching of the stem. One of the characteristics by which the three types of tagetes differ is the height of the stem. The highest stem is Tagetes erecta - about 150 $170 \mathrm{~cm}$ depending on the variety, followed by Tagetes patula $-80-100 \mathrm{~cm}$ and $15-30 \mathrm{~cm}$ in Tagetes signata. The data from the present study show that the height of the stem in plants of the species Tagetes erecta is from 115.8 to 172.4 $\mathrm{cm}$, ie. with the highest stems are the plants from the treated with $1.5 \%$ Panamin variant, and with the lowest - the plants from the untreated variant. The plants from the other treated variants exceeded the control by $39.0 \mathrm{~cm}$ and $54.5 \mathrm{~cm}$ for the variants treated with $0.5 \%$ and $1.0 \%$ Panamin, respectively, and the same variants are lower than the best variant by $11.4 \%$ and $1.2 \%$, respectively. Impressive is the low height of the plants from the control variant $115.8 \mathrm{~cm}$, which do not even reach the height typical for the variety. Stem thickness is an indicator that characterizes the stability of the plant. Tagetes is generally a plant that has many branches on the stem and forms a large number of leaves and flowers. According to Balakrishnan, V. et al., (2007), the fresh weight of Tagetes erecta plants can reach $370.5 \mathrm{~g}$. In addition, the stem and stem branches are quite fragile and easily broken. Therefore, the thickness of the stem at the base is a good prerequisite for the stability of the plant during the growing season. In Tagetes erecta, stem thickness ranged from $1.2 \mathrm{~cm}$ in the control variant to $1.9 \mathrm{~cm}$ in plants treated with $0.5 \%$ Panamin. The differences in the data for this indicator in the treated variants are not large $0.1 \mathrm{~cm}$ and $0.3 \mathrm{~cm}$, respectively, for the plants treated with $1.0 \%$ and $1.5 \%$ Panamin in favor of those treated with $0.5 \%$ Panamin. A similar trend is observed in the number of branches of the stem. With the largest number of branches 67.8 pcs. are the plants treated with $0.5 \%$ Panamin, and the excess over untreated plants is impressive -49.5 pcs. or $270.5 \%$. Plants treated with $1.0 \%$ and $1.5 \%$ Panamin exceeded the control by 23.8 pcs. and 27.4 pcs. or by $130.1 \%$ and $149.7 \%$, and are less branched than the best option by 25.7 . and 22.1 pcs. or by $61.1 \%$ and $48.4 \%$. The height of the stem in Tagetes patula is greatest in plants treated with $1.5 \%$ Panamin - $99.4 \mathrm{~cm}$. They exceed the control plants by $35.7 \mathrm{~cm}$ or $56.1 \%$. Very close values in terms of stem height have the plants from the variant treated with $1.0 \%$ Panamin $-98.7 \mathrm{~cm}$, which are only $0.7 \mathrm{~cm}$ lower than the plants in the best variant. Untreated plants are $23.8 \mathrm{~cm} ; 35.0 \mathrm{~cm}$ and $37.7 \mathrm{~cm}$ lower than those treated with $0.5 \%$, 
75 years of Agricultural University - Plovdiv JUBILEE SCIENTIFIC INTERNATIONAL CONFERENCE Plovdiv 26-28 November 2020
PERSPECTIVES ON AGRICULTURAL SCIENCE AND INNOVATIONS FOR SUSTAINABLE FOOD SYSTEMS
$0.1 \%$ and $1.5 \%$ Panamin, respectively. The thickness of the stem in this species of tagetes varies from $0.8 \mathrm{~cm}$ in untreated plants to $1.2 \mathrm{~cm}$ in treated with $0.5 \%$ Panamin. The values of this indicator are very close when treating plants with concentrations of $1.0 \%$ and $1.5 \%$ Panamin - $1.0 \mathrm{~cm}$ and $0.9 \mathrm{~cm}$, respectively, and the difference with the best option is only $0.2 \mathrm{~cm}$ and $0.3 \mathrm{~cm}$, respectively, or $20.0 \%$ and $33.3 \%$. Regarding the branching of the stem with the largest number of branches is the variant treated with $0.5 \%$ Panamin - 45.8 pcs., Which exceeds the control by 24.1 pcs. or by $111.1 \%$. The plants are much less branched than the variants treated with higher concentrations of Panamin 31.7 pcs. and 30.5 pcs. for the variants treated with $1.0 \%$ and $1.5 \%$ Panamin, respectively. However, the latter variants exceeded the control plants by $46.1 \%$ and $40.6 \%$, respectively, but are less branched than the variant treated with $0.5 \%$ Panamin by $44.5 \%$ and $50.2 \%$, respectively. Stem height in Tagetes signata ranged from $18.4 \mathrm{~cm}$ in untreated plants to $40.1 \mathrm{~cm}$ in $1.5 \%$ Panamin-treated plants. The difference is $21.7 \mathrm{~cm}$ or $117.9 \%$. Variants treated with lower concentrations also significantly exceed untreated plants on this indicator $7.2 \mathrm{~cm}$ and $20.3 \mathrm{~cm}$ is the difference in height in favor of plants treated with $0.5 \%$ and $1.0 \%$ concentration of Panamin in favor of treated plants, respectively. The diameter of the stem in Tagetes signata is the smallest compared to other species - the plants with the thickest stems in Tagetes signata have a $1.9 \mathrm{~cm}$ thick stem, in Tagetes patula $-1.2 \mathrm{~cm}$, and in Tagetes signata $-0.8 \mathrm{~cm}$. In contrast to the other two species, in Tagetes signata with the largest stem diameter are the plants treated with high doses of Panamin $-1.0 \%$ and $1.5 \%$ and in both variants the plants have stems with a thickness of $0.8 \mathrm{~cm}$. The difference with the other two variants plants treated with $0.5 \%$ concentration of Panamin and untreated plants - is not large and is $0.1 \mathrm{~cm}$ and $0.3 \mathrm{~cm}$ or $14.2 \%$ and $60.0 \%$, respectively.
The most strongly branched in Tagetes signata, as in the other two species, are again the plants treated with $0.5 \%$ Panamin. They form an average of 31.4 pcs. branches of a plant. 25.6 pcs. and 27.1 pcs. branches form plants treated with $1.0 \%$ and $1.5 \%$ Panamin, respectively. The three experimental variants exceed the untreated plants in the control by 14.7 pcs., 8.9 pcs. and 10.4 pcs. for variants treated with $0.5 \% ; 1.0 \%$ and $1.5 \%$ Panamin or $88.0 \%, 53.3 \%$ and $62.3 \%$. From the data in this table it is impressive that the plants of all three species Tagetes and Tagetes erecta, and Tagetes patula and Tagetes signata - are the highest when treated with the highest concentration of Panamin used $-1.5 \%$. The use of this concentration does not lead to more branched plants. More strongly branched, with a larger stem diameter and therefore more stable plants were obtained by treatment with a lower concentration of Panamin - namely $0.5 \%$. Tagetes foliage is both a growth and a decorative manifestation according to Bharathi, T. U. et al. (2014). It is believed that plants with more leaves are more decorative, because on their dark green background brightly colored flowers are even more noticeable. The characteristics of the leaves in the present study are presented in Table 3. The number of leaves in Tagetes erecta varies from 48.7 pcs. in untreated plants from the control variant up to 127.8 pcs. in plants treated with 1.5 Panamin. The difference is impressive - 79.1 pcs. or $162.4 \%$. The plants have a larger number of leaves than the other experimental variants 92.7 pcs. for plants treated with $0.5 \%$ Panamin and 110.5 pcs. for those treated with $1.0 \%$ Panamin, the differences compared to the control were 44.0 pcs. and 61.8 pcs. respectively. The size of the leaves also follows the established tendency to increase with increasing concentration of the preparation used. The leaves of the plants treated with $1.5 \%$ Panamin were $14.9 \mathrm{~cm} 2$ larger than those of the plants in the untreated variant, which is an increase of $175.3 \%$. In the variants treated with 
75 years of Agricultural University - Plovdiv JUBILEE SCIENTIFIC INTERNATIONAL CONFERENCE Plovdiv 26-28 November 2020
PERSPECTIVES ON AGRICULTURAL SCIENCE AND INNOVATIONS FOR SUSTAINABLE FOOD SYSTEMS
$0.5 \%$ and $1.0 \%$, the leaf size was $11.4 \mathrm{~cm} 2$ and $19.5 \mathrm{~cm} 2$, respectively, exceeding the leaves of untreated plants by $34.1 \%$ and $129.4 \%$, respectively. Tagetes patula has a larger number of leaves than Tagetes erecta. While in the first type the number of leaves varies from 78.3 pcs. to 188.8 pcs., then the second number of leaves is from 48.7 pcs. up to 127.8 pcs. The largest number of leaves in Tagetes patula were formed by the plants treated with the highest concentration of Panamin - 1.5\% - 188.8 pcs., Exceeding the control and other experimental variants by 110.5 pcs., 43.1 pcs. and 20.5 pcs. The leaf size of this species of Tagetes varies from $3.7 \mathrm{~cm} 2$ to $14.5 \mathrm{~cm} 2$. The largest are the leaves of the plants treated with $1.5 \%$ Panamin $-14.5 \mathrm{~cm} 2$. Untreated plants form leaves with an average size of $3.7 \mathrm{~cm} 2$, which are $2.2 \mathrm{~cm} 2$ and $8.0 \mathrm{~cm} 2$ smaller than the leaves of plants treated with $0.5 \%, 1.0 \%$ and $1.5 \%$ Panamin, respectively. In Tagetes signata, the number of leaves and their size also increase with increasing concentration of the preparation used. The variant treated with $1.5 \%$ Panamin has the largest number of leaves - 101.7 pieces, as the average size of one leaf is $9.9 \mathrm{~cm} 2$.

The influence of foliar fertilization with Panamin on the characteristics of the flowers in species of the genus Tagetes are presented in Table 4. In Tagetes erecta the number of flowers varies from 16.7 pcs. for untreated plants, up to 87.5 pcs. in plants treated with $0.5 \%$ Panamin. The difference is 70.8 pcs. or the number of flowers in the treated variant is 5.24 times higher than in the untreated plants. Similar results were obtained in the plants treated with $1.5 \%$ Panamin - 84.5 pcs. flowers or 5.06 times more than untreated plants. Treatment with $1.0 \%$ Panamin resulted in 73.8 plants. colors, which is 13.7 pcs. colors less than those treated with $0.5 \%$ Panamin, with 10.7 pcs. colors less than those treated with $1.5 \%$ Panamin and 57.1 pcs. flowers less than untreated plants in the control variant. The diameter of the flowers in Tagetes erecta in the treated variants did not show significant differences $-11.4 \mathrm{~cm} ; 10.5 \mathrm{~cm}$ and $10.8 \mathrm{~cm}$ for $0.5 \%$ treated plants, respectively; $1.0 \%$ and $1.5 \%$ Panamin. However, the difference between the treated variants and the untreated plants is significant $-3.9 \mathrm{~cm} ; 3.0 \mathrm{~cm}$ and $3.3 \mathrm{~cm}$ respectively for those treated with $0.5 \% ; 1.0 \%$ and $1.5 \%$ Panamin at $7.5 \mathrm{~cm}$ in diameter of the control plants, or $52.0 \% ; 40.0 \%$ or $44.0 \%$ more for the treated variants. The number of petals determines the ornateness of the flowers. In the case of tagetes, it is accepted that the more showy colors are more decorative. The plants treated with $1.5 \%$ Panamin have the largest number of petals - 164.1 pcs., With 76.6 pcs., 35.7 pcs. and 28.5 pcs. more than untreated and $0.5 \%$ and $1.0 \%$ Panamin treated plants, respectively. The number of flowers in Tagetes patula is greater than the number of flowers in Tagetes erecta, as the plants are generally lower, more compact, with more stem branches, most of which end in flowers. The plants with $1.5 \%$ Panamin have the largest number of flowers 99.5 pcs. for 1 plant, with 80.6 pcs. more than the number of flowers per plant in the control variant with untreated plants. The number of flowers for growth in the other two treated variants - $0.5 \%$ and $1.0 \%$ Panamin - are 85.4 pcs. and 91.7 pcs., with 66.8 pcs. and 73.1 pcs. more than the plants in the control variant. The difference compared to the version with the most colors - treated with 1.5\% Panamin is respectively $14.1 \mathrm{pcs}$. and $7.8 \mathrm{pcs}$. The diameter of the flowers in Tagetes patula increases with increasing concentration of Panamin treatment. Thus, the untreated plants have the smallest diameter of flowers $-2.5 \mathrm{~cm}$, followed by those treated with $0.5 \% ; 1.0 \%$ and $1.5 \%$ Panamin -3.8 $\mathrm{cm}$, respectively; $4.7 \mathrm{~cm}$ and $5.1 \mathrm{~cm}$. The same trend is observed in the number of petals. The plants with the highest concentration of Panamin - 1.5\% - 93.1 pcs. Have the largest number of flower petals. They exceed the other variants by 51.8 pcs ;; 24.4 pcs. and 7.5 pcs. respectively, for untreated plants and for those treated with $0.5 \%$ and $1.0 \%$ Panamin 
75 years of Agricultural University - Plovdiv JUBILEE SCIENTIFIC INTERNATIONAL CONFERENCE Plovdiv 26-28 November 2020
PERSPECTIVES ON AGRICULTURAL SCIENCE AND INNOVATIONS FOR SUSTAINABLE FOOD SYSTEMS concentrations. The difference between the number of petals in the control variant and the best variant is impressive - the plants of the variant treated with $1.5 \%$ Panamin form $125.42 \%$ more petals than untreated plants.

The tendency to increase the decorative characteristics with increasing concentration of treatment with Panamin foliar fertilizer is very clear in the last type of tagetes - Tagetes signata. The plants treated with $1.5 \%$ Panamin have the largest number of flowers - 93.1 pcs, exceeding $67.8 \mathrm{pcs}$. control variant with untreated plants or by $267.98 \%$. The diameter of the stem of untreated plants is $1.1 \mathrm{~cm}$, or $0.7 \mathrm{~cm} ; 1.6 \mathrm{~cm}$ and $2.3 \mathrm{~cm}$ smaller than the diameter of the stem in plants treated with $0.5 \%$ respectively; $1.0 \%$ and $1.5 \%$ Panamin, with the difference in percentages between the control and the variant with the thickest stem being $209.1 \%$. The results are similar in the number of petals. They are 27.1 pcs. in the control variant and with 58.6 pcs., or 85.7 pcs. or $216.2 \%$ more at best in plants treated with $1.5 \%$ Panamin. With 21.3 pcs. and 37.8 pcs. more petals from the control variant formed the plants in the variants treated with $0.5 \%$ and $1.0 \%$ Panamin, respectively. Our beneficial effect of the biomineral fertilizer PanaminAgro is in confirmation of the results obtained by Valchev, D. and D. Valcheva (2019) which achieve an increase in yield in wheat and barley by $26.6 \%$ and $25.2 \%$, respectively, when applying PanaminAgro in a dose $150 \mathrm{~g} / \mathrm{dka}$ for pre-winter and spring treatment. The same authors also reported a significant increase in grain quality in both crops. Similarly, a number of authors report on research conducted in the field of horticulture and vegetable crops and obtained high positive results, namely an increase in yields of onions, tomatoes and peppers, respectively, by $43 \%$, $19.4 \%$ and $33 \%$ and a significant increase in vitamin $\mathrm{C}$ in the fruits of the studied crops. For ornamental plants, both flowering and woody, there are no published data from the PanaminAgro study. Our experiment shows that the use of PanaminAgro biomineral fertilizer can be successfully applied in the production of seedlings from seed-propagated annual flowering species to obtain plants with pronounced decorative qualities, high tolerance to environmental stress and disease resistance.

\section{CONCLUSIONS}

1. In foliar application on plants of the three Tagetes species with the best developed root system, the plants are treated with a concentration of PanaminAgro 1.5\%.

2. The highest are the stems of plants treated with a concentration of PanaminAgro 1.5\%. Applying foliar fertilization with PanaminAgro in a concentration of $0.5 \%$ yields lower, more compact plants with a larger stem diameter, ie. more stable and resilient.

3. The most suitable concentration for obtaining well-leaved plants is $1.5 \%$ PanaminAgro.

4. The production of plants with more decorative flowers was found when applying PanaminAgro in a concentration of $1.5 \%$. The foliar application of PanaminAgro results in the production of plants without blind branches on the stem. 
75 years of Agricultural University - Plovdiv JUBILEE SCIENTIFIC INTERNATIONAL CONFERENCE Plovdiv 26-28 November 2020
PERSPECTIVES ON AGRICULTURAL SCIENCE AND INNOVATIONS FOR SUSTAINABLE FOOD SYSTEMS

Table 1. Influence of leaf treatment with Panamin on the characteristics of the root system in species of the genus Tagetes

\begin{tabular}{|c|c|c|c|c|c|c|c|c|c|}
\hline \multirow{2}{*}{ Variants } & \multicolumn{3}{|c|}{ Tagetes erecta } & \multicolumn{3}{c|}{ Tagetes patula } & \multicolumn{3}{c|}{ Tagetes signata } \\
\cline { 2 - 10 } & $\begin{array}{c}\text { lenght } \\
\mathrm{cm}\end{array}$ & $\begin{array}{c}\text { number of } \\
\text { branches }\end{array}$ & $\begin{array}{c}\text { volume } \\
\mathrm{cm}^{3}\end{array}$ & $\begin{array}{c}\text { lenght } \\
\mathrm{cm}\end{array}$ & $\begin{array}{c}\text { number of } \\
\text { branches }\end{array}$ & $\begin{array}{c}\text { volume } \\
\mathrm{cm}^{3}\end{array}$ & $\begin{array}{c}\text { lenght } \\
\mathrm{cm}\end{array}$ & $\begin{array}{c}\text { number } \\
\text { of } \\
\text { branches }\end{array}$ & $\begin{array}{c}\text { volume } \\
\mathrm{cm}^{3}\end{array}$ \\
\hline $\mathrm{K}$ & 11.4 & 178.4 & 257.8 & 5.8 & 93.4 & 94.8 & 3.2 & 48.7 & 68.7 \\
\hline 0.5 & 18.7 & 201.5 & 278.4 & 5.3 & 107.8 & 123.1 & 4.1 & 55.6 & 73.8 \\
\hline 1.0 & 17.8 & 218.7 & 293.5 & 7.8 & 111.5 & 117.8 & 4.5 & 61.7 & 87.5 \\
\hline 1.5 & 18.9 & 194.8 & 287.8 & 7.7 & 121.7 & 131.8 & 4.4 & 73.2 & 90.3 \\
\hline $5 \%$ & 7.36 & 98.11 & 108.34 & 3.43 & 88.43 & 67.56 & 1.4 & 23.43 & 45.38 \\
$\mathrm{GD} 1 \%$ & 8.01 & 101.04 & 143.71 & 4.29 & 94.15 & 76.88 & 2.3 & 31.44 & 49.76 \\
$0,1 \%$ & 8.89 & 128.23 & 176.57 & 5.67 & 109.88 & 86.53 & 2.9 & 42.61 & 53.60 \\
\hline
\end{tabular}

Table 2. Influence of leaf treatment with Panamin on stem characteristics in species of the genus Tagetes

\begin{tabular}{|c|c|c|c|c|c|c|c|c|c|}
\hline \multirow[b]{2}{*}{ Variant } & \multicolumn{3}{|c|}{ Tagetes erecta } & \multicolumn{3}{|c|}{ Tagetes patula } & \multicolumn{3}{|c|}{ Tagetes signata } \\
\hline & height $\mathrm{cm}$ & $\begin{array}{c}\text { diameter } \\
\mathrm{cm}\end{array}$ & $\begin{array}{l}\text { number of } \\
\text { branches }\end{array}$ & height $\mathrm{cm}$ & $\begin{array}{c}\text { diameter } \\
\mathrm{cm}\end{array}$ & $\begin{array}{l}\text { number o } \\
\text { branches }\end{array}$ & $\begin{array}{c}\text { heigh } \\
\mathrm{cm}\end{array}$ & $\begin{array}{c}\text { diameter } \\
\mathrm{cm}\end{array}$ & $\begin{array}{c}\text { number of } \\
\text { branches }\end{array}$ \\
\hline K & 158.8 & 1.2 & 18.3 & 63.7 & 0.8 & 21.7 & 18.4 & 0.5 & \begin{tabular}{|l|}
16.7 \\
\end{tabular} \\
\hline 0.5 & 154.8 & 1.9 & 67.8 & 87.5 & 1.2 & 45.8 & 25.6 & 0.7 & 31.4 \\
\hline 1.0 & 170.3 & 1.8 & 42.1 & 98.7 & 1.0 & 31.7 & 38.7 & 0.8 & 25.6 \\
\hline 1.5 & 172.4 & 1.6 & 45.7 & 99.4 & 0.9 & 30.5 & 40.1 & 0.8 & 27.1 \\
\hline $5 \%$ & 111.23 & 0.6 & 29.84 & 40.32 & 1.2 & 11.23 & 12.77 & 0.1 & 11.34 \\
\hline GD $1 \%$ & 127.61 & 1.1 & 34.51 & 43.17 & 1.7 & 18.32 & 17.34 & 0.2 & 17.44 \\
\hline $0,1 \%$ & 132.18 & 1.9 & 39.47 & 46.65 & 2.1 & 20.11 & 19.58 & 0.4 & 18.51 \\
\hline
\end{tabular}

Table 3. Influence of foliar fertilization with Panamin on leaf characteristics in Tagetes species

\begin{tabular}{|c|c|c|c|c|c|c|}
\hline \multirow{2}{*}{ Variants } & \multicolumn{2}{|c|}{ Tagetes erecta } & \multicolumn{2}{c|}{ Tagetes patula } & \multicolumn{2}{c|}{ Tagetes signata } \\
\cline { 2 - 7 } & number & size of 1 leaf $\mathrm{cm}^{2}$ & number & size of 1 leaf $\mathrm{cm}^{2}$ & number & size of 1 leaf $\mathrm{cm}^{2}$ \\
\hline $\mathrm{K}$ & 48.7 & 8.5 & 78.3 & 3.7 & 60.4 & 1.2 \\
\hline 0.5 & 92.7 & 11.4 & 145.7 & 5.9 & 80.7 & 4.2 \\
\hline 1.0 & 110.5 & 19.5 & 168.3 & 11.7 & 92.5 & 7.8 \\
\hline 1.5 & 127.8 & 23.4 & 188.8 & 14.5 & 101.7 & 9.9 \\
\hline $5 \%$ & 40.32 & 6.3 & 36.30 & 2.4 & 35.07 & 0.3 \\
GD $1 \%$ & 43.57 & 7.4 & 38.54 & 5.8 & 39.11 & 1.8 \\
$0,1 \%$ & 45.12 & 8.1 & 41.33 & 9.1 & 42.07 & 2.8 \\
\hline
\end{tabular}

Table 4. Influence of leaf treatment with $\mathrm{cm}$ on color characteristics in species of the genus Tagetes

\begin{tabular}{|c|c|c|c|c|c|c|c|c|c|}
\hline \multirow{2}{*}{ Variants } & \multicolumn{3}{|c|}{ Tagetes erecta } & \multicolumn{3}{c|}{ Tagetes patula } & \multicolumn{3}{c|}{ Tagetes signata } \\
\cline { 2 - 10 } & number & $\begin{array}{c}\text { diameter } \\
\text { cm }\end{array}$ & $\begin{array}{c}\text { number } \\
\text { of petals }\end{array}$ & number & $\begin{array}{c}\text { diameter } \\
\mathrm{cm}\end{array}$ & $\begin{array}{c}\text { number } \\
\text { of petals }\end{array}$ & $\begin{array}{c}\text { number } \\
\text { niameter } \\
\mathrm{cm}\end{array}$ & $\begin{array}{c}\text { number of } \\
\text { petals }\end{array}$ \\
\hline K & 16.7 & 7.5 & 87.5 & 18.6 & 2.5 & 41.3 & 25.3 & 1.1 & 27.1 \\
\hline 0.5 & 87.5 & 11.4 & 128.4 & 85.4 & 3.8 & 68.7 & 67.8 & 1.8 & 48.4 \\
\hline 1.0 & 73.8 & 10.5 & 135.6 & 91.7 & 4.7 & 85.6 & 84.5 & 2.7 & 64.9 \\
\hline 1.5 & 84.5 & 10.8 & 164.1 & 99.5 & 5.1 & 93.1 & 93.1 & 3.4 & 85.7 \\
\hline $5 \%$ & 8.2 & 3.7 & 61.8 & 23.43 & 0.4 & 32.7 & 12.3 & 0.9 & 11.8 \\
GD 1\% & 9.3 & 4.2 & 66.5 & 31.32 & 1.8 & 41.9 & 17.8 & 1.3 & 15.3 \\
$0,1 \%$ & 11.9 & 6.8 & 69.3 & 54.15 & 2.3 & 48.3 & 20.5 & 1.5 & 16.3 \\
\hline
\end{tabular}


75 years of Agricultural University - Plovdiv

JUBILEE SCIENTIFIC INTERNATIONAL

CONFERENCE Plovdiv 26-28 November 2020
PERSPECTIVES ON AGRICULTURAL SCIENCE AND INNOVATIONS FOR SUSTAINABLE FOOD SYSTEMS

\section{REFERENCES}

Al Badawy, Ahmed, A., Abdalla, N.M. and Mohamed, M.A. (1993) The combined effect of cycocel and foliar fertilizers on Tagetes minuta. L. Plats, Proceedings of the $20^{\text {th }}$ Plant growth Regulation Society of America, 114-127.

Atanasova, B., Kotopanova, Ya., Filipova, I. (1999). Izpitvane na kompleksniya techen tor "Vege" varhu dobiva i kachestvoto na reznici ot hrizantema. [Testing of complex liquid fertilizer "Vege" on the yield and quality of chrysanthemum cuttings].Sb. Nauchni trudove [Scientific works], VI nauchnopraktichna konferenciya "Ekologichni problemi na zemedelieto", Plovdiv, XLIV, 3, 95-102.

Atanasova, B., Kotopanova, Ya., Haralampieva, V., Filipova, I. (2000). Prouchvane na kompleksnya techen tor "Vege" pri proizvodstvoto na posadachen material ot mini karamfil. [Study of complex liquid fertilizer "Vege" in the production of planting material from mini carnations.] Pochvoznanie, agrohimia i ekologiya. XXXV, 2, 26-29.

Atanasova, B., Kotopanova, Ya., Slavov, D., Valchovski, I.. (2007). Prouchvane vliyanieto na huminov tor Humustim varhu dobiva i kachestvoto na mini karamfil. [Study of the influence of Humustim humic fertilizer on the yield and quality of mini carnation.] Humustim - dar ot prirodata. Torat na badeshteto. "Dimi" 99 OOD, 144-147.

Atanasova, B. (2010). Prouchvane na Lumbrikol varhu nachalnite fazi ot rasteja i razvitieto na mini karamfil. I. Izpitvane vliyanieto na koncentraciyata. [Study of Lumbricol on the initial stages of growth and development of mini carnations. I. Test the effect of concentration.] Pochvoznanie, agrohimia i ekologiya. XLV, 1-4, 224226.

Atanasova, B. (2012). Pochveno tretirane na mini karamfil (Spray carnation) s universalniya tor Horti grou. [Soil treatment of mini carnation (Spray carnation) with the universal fertilizer HortiGrow.] Godishnik Naukata, obrazovanieto i izkustvoto prez 21 vek. Blagoevgrad, 6, 1, 328-334.

Atanasova, B. (2012). Biologichno prouchvane na noviya organichen tor Baykal pri mini karamfil (Spray carnation). [Biological study of the new organic fertilizer Baikal in mini carnation (Spray carnation).]. Sbornik ot dokladi na IX Natsionalna nauchno-tehnicheska konferenciya $\mathrm{s}$ mezhdunarodno uchastie Ekologiya i zdrave, Plovdiv, 237-242.

Atanassova B., Nencheva, D. (2012). Use of Evironmentally Friendly Biological Fertilizer Lumbricol in Cultivation of Pot Carnation. Proceedings "Seminar of ecology", Sofia, 20-25.

Atanassova B. (2013). Foliar treatment of Gypsophila with the universal fertilizer HortiGrow. Proceedings "Seminar of ecology", Sofia, 160-165.

Balakrishnan, V., Jawaharlal, M., Senthil Kumar, T. and Ganga, M. (2007). Response of micro-nutrients on flowering, yield and xanthophylls content in African marigold (Tagetes erecta L.). Journal of Ornamental Horticulture 10 (3), 153-156.

Bharathi, T. U. and Jawaharlal, M. (2014). Evaluation of African marigold (Tagetes erecta. L.) genotypes for growth and flower yield under Coimbatore condition. Trends in Biological Science 7(16), 2197-2201.

Benk, E., Trieber, H. and Bergmann, R. (1976). Detection of Tagetes extractin orange concentrates considering raw materials 
75 years of Agricultural University - Plovdiv JUBILEE SCIENTIFIC INTERNATIONAL CONFERENCE Plovdiv 26-28 November 2020
PERSPECTIVES ON AGRICULTURAL SCIENCE AND INNOVATIONS FOR SUSTAINABLE FOOD SYSTEMS and beverages. Riechst, Aromen and Koerpen., 26(10), 216, 218, 220-221.

Das, P., Bose, T. K. and Roy, P.K. (1975). Effect of growth regulators on the photoperiodic response in short and long day plants. Plant Science, 7, 41-44.

Dumanovsky, F., Maric, L., Kusar, M., Rac, J., Simon, T., Binicki, M., Peraic, I and Pavlov, M. (1980). Effect of the addition of Tagetes to the rations of laying hens on egg yolk colour. Veterinaria(Sarajeve), 29, 1, 205-209.

El-Kinany, R. and Gaber, A. (2014). Improving medicinal and landscape values of saltstressed Bellisperennis, Calendula officinalis and Tagetes patula Plants by Applying Humic Acid or Proline.Ph.Thesis, Fac.Agric., Damanhour Univ., Egypt. 371.

Filipova, I., Atanasova, B., Kotopanova, Ya. (1999). Vliyanie na kompleksniya tor "Vege" varhu dobiva na semena ot astri. [Influence of complex liquid fertilizer "Vege" on the yield of aster seeds.] $S b$. Nauch. tr. [Scientific works], IV nauchno-praktichna konferentsia "Ekologichni problemi na zemedelieto", XLIV, 3, 79-86.

Gowda, J.V.N. and Jayanthi, R. (1994). Effect of Cycocel and maleic hydrazide on growth and flowering of African marigold (tagetes arecta). Mysore Journal of Agricultural and Scienceq 26, 2, 175-179.

Hore, J. K. and Sen, S.K. (1986). Effect of some chemicals on the performance of the French marigold tagetes patula. Environmental Ecology, 4, (4), 589-595.

Ivanova, V., Rankov, V., Tafradzhiyski, O. (1995). Vliyanie na suspenzionnite torove "Laktofol" varhu rastezhnite i dekorativni proyavi na hrizantemata. [Influence of "Lactofol" suspension fertilizers on the growth and decorative manifestations of the chrysanthemum.]
Sbornik ot dokladi na Yubileyna nauchna sesiya "Ustoychivo zemedelie $\mathrm{v}$ usloviyata na prehoda kam pazarna ikonomika", Plovdiv, 2, 5-9.

Ivanova, V., Kadum, I. (1996). Rizogenna sposobnost na reznici ot hrizantema (Chrysanthemum indicum L.), tretirani sas suspenzionen tor 'Laktofol'. [Rhizogenic ability of chrysanthemum cuttings (Chrysanthemum indicum L.) treated with Lactofol suspension fertilizer.] Sb. Dokladi ot Vtora nauchna konferenciya" Razmnozhavane na dekorativni rasteniya", Sofiya, 200-204.

Ivanova, V., Nikolov, P., Tafradzhiyski, O. (2005). Prilozhenie na biohumusa pri proizvodstvo na razsad ot ednigodishni cvetya. [Application of biohumus in the production of seedlings of annual flowers.] Yubileyna nauchna konferenciya "Sastoyanie i problemi na agrarnata nauka i obrazovanie", Nauchni trudove, L, (6), 477-482.

Kasumov, M. A. (1984) New food dyes for butterfat, biscuit, caramel and liquourvodka industries. Dokl Academie Nauk Azerb SSr, 40, (1), 69-74.

Kasumov, M.A. (1991). Novel yellow food colorings for confectionery. Pishch Promst (Moskow) (2), 57-60.

Kotopanova, Ya., Atanasova, B., Filipova, I. (1999). Biologichno prouchvane na kompleksniya techen tor "Vege" varhu dobiva na semena ot neven /Calendula officinalis/. [Biological study of complex liquid fertilizer "Vege" on the yield of calendula seeds / Calendula officinalis /]. Sb. Nauchni trudove [Scientific works], IV nauchnopraktichna konferenciya s mezhdunarodno uchastie „Ekologichni problemi na zemedelieto", Plovdiv, XLIV, (3), 87-94.

Kotopanova, Ya., Atanasova, B. (2008). Prilozhenie na kompleksniya mineralen 
75 years of Agricultural University - Plovdiv JUBILEE SCIENTIFIC INTERNATIONAL CONFERENCE Plovdiv 26-28 November 2020
PERSPECTIVES ON AGRICULTURAL SCIENCE AND INNOVATIONS FOR SUSTAINABLE FOOD SYSTEMS techen tor Kristalon pri mini karamfila. [Application of complex mineral liquid fertilizer Kristalon in mini cloves.] Sb. dokladi na IV Natsionalna nauchnotehnicheska konferenciya „Ekologiya i zdrave“, Plovdiv, 315-320.

Kotopanova, Ya., Nencheva, D. (2008). Izpitvane na ekologichno chistiya tor "Humostim" varhu kachestvoto na saksiyna hrizantema. [Testing of the ecologically clean fertilizer "Humustim" on the quality of potted chrysanthemum.] Ekologichno inzhenerstvo I opazvane na okolnata sreda., 7, 2-3, 103-105.

Kumar, P., Singh, D. and Kumar, S. (2010) Effect of pre- harvest micronutrient foliar spray on growth, flowering and seed production in marigold. Progressive Agriculture 10(1): 182-183.

Kumar, S.S., Nalwadi, U. G. and Basarkar, P.W. (1991). Influence of moisture stress on the accumulation of phenols in marigold (tagetes erecta). Geobios, 18,4 165-168.

Malinova, R. (2007). Badeshteto e na ekologichnoto zemedelie, a zalog za toba e organichnoto torene. [The future lies in organic farming, and the key to that is organic fertilization]. "Humustim - dar ot prirodata. Torat na badeshteto". Dimi 99 OOD, 27-28.

Narahari, D., Venugopal, K., Raj, A. G., Kothandaraman, P. and Kumoraraj, R. (1981). Marigold flower meal as a source of xanthophyll for egg yolk pigmentation. Indian Journal of Poultry Science, 16, (4) 409-411.

Pal, P and Ghosh, P. (2010). Effect of different sources and levels of potassium on growth, flowering and yield of African marigold (Tagetes erecta Linn.) cultivar Siracole. Indian Journal of NaturalProduct and Resources, 1 (3), 371-375.

Peat, J.R. and Summerfield, R.J. (1977).
Environmental and cultural effects on vegetative growth and flowering of selected bedding ornamentals, II. Nightbreak lighting and gibberelic acid applications. Science of horticulture, 7 , $181-88$.

Sanghamitra, V., Vijaya, B. and Subbaramamma, P. (2000). Effect of different sources and levels of potassium on vegetative, reproductive parameters of marigold (Tagetes erecta Linn.) cultivar'Maxima Yellow'M. J. of Ornamental Hort., 16 (1\&2), 86-94.

Sapundzhieva, Kr., Ivanova, V., Kartalska, Y., Kanalieva, K. (2001). Vliyanie na biostimulatora Agrostemin I granuliraniya tor Hortigrou varhu vegetativnite I dekorativni proyavi na Cyclamen persicum. [Influence of the biostimulator Agrostemin and the granulated Hortigrow fertilizer on the vegetative and decorative phenomena of Cyclamen persicum.] Yubileyna nauchna konferentsiya "80 godini visshe obrazovanie", Nauchni trudove, XLVI, 4, 157-162.

Sengalevich, G. (2007). Evropeyskata obshtnost iziskva ekologizatsia na agrohimikalite. "Humustim - dar ot prirodata. [The European Community calls for the greening of agrochemicals.]Torat na badeshteto". Dimi 99 OOD, 21-26.

Sharova, N.L. and Savva, V.G. (1974). Trace elements in flower growing. Sadovod. Vinograd, Vinedel, Mold., 29, 1 43-45.

Smalley, T.J., Lasseigne, Ft., Mills, H.A. and Hussey, G. G. (1993) Effect of aluminium on growth and chemical composition of marigolds. Journal of Plant Nutrition, 16, 8 1375-1384.

Takki, K., Nakamura, M., Kumai, H., Hattori, T., and Kondo, A. (1991). Effect of marigold xanthophyll suplementation to a formulated diet on pigmentation of yellow tail. Suisan Zoshoku, 39,1 9-13. 
75 years of Agricultural University - Plovdiv JUBILEE SCIENTIFIC INTERNATIONAL CONFERENCE Plovdiv 26-28 November 2020
PERSPECTIVES ON AGRICULTURAL SCIENCE AND INNOVATIONS FOR SUSTAINABLE FOOD SYSTEMS
Tsurushima, H. and Date, N. (1971). Effects of nitrogen, phosphorus and potassium on the growth and flowering of some breeding plants. Engei Gakkai Zasshi, 40, 4, 407-415.

Valchev, D. and Valcheva, D. (2019). Study on the influence of Panamin leaf fertilizer on plant development, resistance to abiotic stress, productivity and grain quality of wheat and barley Vol. Journal of Agriculture and Plant Sciences, 1, 17.

Valchovski, I., Tosheva, E., Petkova, Z. (2007). Sravnitelno izpitvane na nyakoi listni torove varhu produktivnostta na raygras, otglezhdan na razlichni tipove pochva. [Comparative testing of some foliar fertilizers on the productivity of ryegrass grown on different soil types.] Nauchni dokladi ot mezhdunarodna konferenciya 60 godini Institut po pochvoznanie "N. Pushkarov". Pochvoznanieto - osnova za ustoichivo zemedelie i opazvane na okolnata sreda. Sofia, 295-299.

Wild, R. and Dobrovolny, H. (1976). Detection of marigold flower extracts in orange products by high pressure liquid chromatography. Brauwissenshar, 29, 4, 93-100.

Zapryanova, N., Atanasova, B. (2008). Izpitvane na produkta "MEGAGRIYN" - prirodno sredstvo za foliarno torene pri nyakoi saksiyni kulturi. [Testing of the product "MEGAGREEN" - a natural means of foliar fertilization in some potted crops.] Mezhdunarodna nauchna konferenciya " Balgarskata nauka I Evropeyskoto izsledovatelsko prstranstvo", Stara Zagora, el. nositel.

Zapryanova N., Atanassova. B. (2013). Study of the effect of the organic product Lumbricol on the growth and development of pot flower seedlings impatiens /Impatiens New-Guineal and petunia /Petunia $x$ hybrid/. Journal of Mountain Agriculture on the Balkans,
Institute of Mountain Stockreeding and Agriculture, Troyan, Bulgaria, V.16, 4, 1035-1048. 